\title{
Study to Assess Age Predilection of Malnutrition in Preschool Children
}

\author{
Anil Gupta \\ Post-doctoral Fellow in Biochemistry, \\ College of Allied Health Sciences, Srinivas University, Mangaluru, India \\ E-mail : anilfzk2323@yahoo.com
}

Type of the Paper: Case Report.

Type of Review: Peer Reviewed.

Indexed In: OpenAIRE.

DOI: https://doi.org/10.5281/zenodo.3411840.

Google Scholar Citation: IJHSP

\section{How to Cite this Paper:}

Anil, Gupta. (2019). Urinary Study to Assess Age Predilection of Malnutrition in Preschool Children. International Journal of Health Sciences and Pharmacy (IJHSP), 3(2), 5-10.

DOI: https://doi.org/10.5281/zenodo.3411840.

International Journal of Health Sciences and Pharmacy (IJHSP)

A Refereed International Journal of Srinivas University, India.

IFSIJ Journal Impact Factor for 2019-20 = 3.968

(C) With Author.

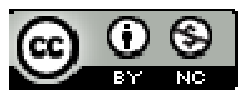

This work is licensed under a Creative Commons Attribution-Non Commercial 4.0 International License subject to proper citation to the publication source of the work.

Disclaimer: The scholarly papers as reviewed and published by the Srinivas Publications (S.P.), India are the views and opinions of their respective authors and are not the views or opinions of the SP. The SP disclaims of any harm or loss caused due to the published content to any party. 


\title{
Study to Assess Age Predilection of Malnutrition in Preschool Children
}

\author{
Anil Gupta \\ Post-doctoral Fellow in Biochemistry, \\ College of Allied Health Sciences, Srinivas University, Mangaluru, India \\ E-mail : anilfzk2323@yahoo.com
}

\begin{abstract}
Background : Age of children is the important demographic factor that is involved in nutritional status of children. The preschool age of children is the formative period in which growth and development of children occur. The deficiency of calories and minerals in the preschool age could result in to malnutrition in children.

Participants and Methods : Present study was comprised of total 440 children which were selected through two stage random sampling method. The children between 2 years to below 5 years were the sampling units. The study was conducted at the city Fazilka in Punjab in India.

Results and Discussion : The study population was comprised of total 440 preschool which were categorized into three age groups as $2 \mathrm{y}$ to $3 \mathrm{y}$ with children $(\mathrm{n} / \mathrm{N}=169 / 440)$ representing $38.4 \%$ in schools, other age group between above $3 y$ to $4 y$ with children $(\mathrm{n} / \mathrm{N}=146 / 440)$ representing 33\% in anganwadis and the age group above $4 y$ to below 5 years with children $(\mathrm{n} / \mathrm{N}=125 / 440)$ representing $28.4 \%$. The stunting in children in 2-3 years age group showed 2.47 times higher chances than the stunting probability in children above 3 to below 5 years age. The Odd ratio between age groups and pallor in preschool children was $(\mathrm{OR}=0.1986 / 0.4728)=(0.42)$ at $95 \%$ C. I. of $(0.260$ to 0.628$)$.

Conclusion : Age of children is significantly associated with stunting, pallor and dental caries in children.
\end{abstract}

Keywords: Stunting, Dental caries, Malnutrition, Nutrition.

\section{INTRODUCTION :}

The malnutrition is the outcome of the food crisis, poverty, hunger, and presence of chronic diseases. According to an estimate, nearly 1.3 billion world's population is living in poverty (World bank 2012 [1]). The poor sanitation, unhygienic conditions, and use of contaminated food and water lead to gastric infection in growing children, especially in developing nations. It is presumed that a child under age of five years suffer from annearly 3 diarrheal attacks in an year in developing countries (Kosek et al. 2003 [2]). Irreversible poverty condition is predisposed to poor environmental condition that leads to diarrhoea in preschool children. The enteric infection manifests as improper growth and development of children

Stunting is manifested as deficient height for age. It is indicated by deficiency in linear growth of the body of the child. It is estimated as the height for age of the child under $(<-2$ standard deviation of the median of the reference population. The stunting is the outcome of the chronic deficiency in nutrition, poor sanitation and occurrence of disease. Stunting is the main hindrance in the growth of preschool children that is prevalent in 165 million populations of children worldwide by 2011 (Black et al. 2013 [3]). Pallor is the yellowish discoloration in the nail beds, skin, mucosa and conjunctiva in eyes. It is the sign of anemia in children. Pallor is a valuable sign in screening the anemia in children and pregnant women in villages and primary health centers where laboratory facility is unavailable (Weber et al. 1997 [4]).

Dental caries in preschool children is the microbial disease of the hard tissues of oral cavity. It damages the enamel and dentin of 
teeth and result into cavitation in affected teeth.

The dental caries in children and oral hygiene are interrelated with each other and also influence the growth and development of children (Mohammadi et al. 2012 [5]).

\section{RATIONALE :}

The information regarding the age predilection of malnutrition among the preschool children in Fazilka city in state of Punjab in India formed the basis of the execution of the present study

\section{OBJECTIVES :}

$\checkmark$ To assess age predilection with stunting in preschool children in Fazilka city in India.

$\checkmark$ To assess age predilection with wasting in preschool children in Fazilka city in India.

$\checkmark$ To assess age predilection with pallor in preschool children in Fazilka city in India

$\checkmark$ To assess age predilection with diarrhoea in preschool children in Fazilka city in India

$\checkmark$ To assess age predilection with dental caries in preschool children in Fazilka city in India

\section{PARTICIPANTS AND METHODS :}

Research design :

Prospective, descriptive, observational and cross-sectional research design was adopted for study.

Sampling design :

Study area

Study was executed in city Fazilka in Punjab state in India. This city is located at Indo-Pak border in state of Punjab in India. According to Census of India, 2011, the city has a population of 67,424 , comprised of $52 \%$ males and $48 \%$ females. The $13 \%$ population of the city is made up of children below 6 years of age.

Sample frame and sampling unit

The total preschool children in between 2 years and below 5 years of age residing Fazilka city formed the sampling frame of study and the preschool children were the sampling units.

Sample selection criteria :

Inclusion criteria
- Children in between 2 years and under 5 years of age

- Children who resided in Fazilka city in Punjab in India

- Boys and girls were selected for study

- Children who participated in the physical examination and anthropometric measurement.

Exclusion criteria

- Children who were below 2 years and above 5 years of age, were excluded.

- Children who were ill at the time of examination were excluded

- Children who were crying at the time of examination were excluded from the study.

Sampling methods :

Random, two-stage cluster sampling method was used.

Data collection design

Type of data

- Primary data for the study was collected.

Data collection instrument

Interview schedules were employed for keeping record of the demographic, anthropometric and clinical data of the participants.

Data collection technique

- Direct observation and face to face interview were conducted to assess physical characteristics, demographic characteristics, and frequency of diarrhoea episodes.

- Inspection method: Pallor was assessed by examination of nail beds

- Anthropometric estimation

- Height of participant was assessed by the vertical wooden height board. The children were asked to stand straight on the wooden board. Height was measured in centimeter units.

- Weight was measured by a digital weighing scale. The children were helped to stand on the scale barefooted with wearing light clothes. The weights of children were recorded in kilogram units.

Cut offs

- The standard deviation (<-2SD) was implied as cutoff point for defining stunting, underweight and wasting as recommended by the WHO.

Ethical approval : 
Approval was obtained from the head of institution to conduct the present study.

Consent :

Objectives of the study were communicated to the teachers and parents in the schools, anganwadis and slums areas. Oral consent was obtained.

Statistical design :

Descriptive analysis

Data points were put into tables.

The study variables were interpreted in percentage $(\mathrm{n} \%)$, frequency $(\mathrm{n} / \mathrm{N})$, and prevalence modes.

Correlation analysis

Odds ratio was calculated with 95\% confidence interval.

Testing of hypothesis was performed by Chisquare test for independence.

\section{RESULTS :}

\section{Demographic characteristics}

1. The study population was comprised of total 440 preschool which were categorized into three age groups as $2 \mathrm{y}$ to $3 \mathrm{y}$ with children $(\mathrm{n} / \mathrm{N}=169 / 440)$ representing $38.4 \%$ in schools, other age group between above $3 y$ to $4 y$ with children $(\mathrm{n} / \mathrm{N}=146 / 440)$ representing $33 \%$ in anganwadis and the age group above $4 y$ to below 5 years with children $(\mathrm{n} / \mathrm{N}=125 / 440)$ representing $28.4 \%$ in slums, as in Table 1 .

Table1: Age-wise Distribution of Participants

\begin{tabular}{|l|l|l|}
\hline $\begin{array}{l}\text { Demographic } \\
\text { Characteristics }\end{array}$ & $\begin{array}{l}\text { Percentage } \\
\text { (n\%) }\end{array}$ & $\begin{array}{l}\text { Frequency } \\
\text { (n/N) }\end{array}$ \\
\hline $2 \mathrm{y}$ to $3 \mathrm{y}$ & $38.4 \%$ & $169 / 440$ \\
\hline$>3 \mathrm{y}$ to $4 \mathrm{y}$ & $33 \%$ & $146 / 440$ \\
\hline$>4 \mathrm{y}$ to $<5 \mathrm{y}$ & $28.4 \%$ & $125 / 440$ \\
\hline
\end{tabular}

2. The study group was made up of total 440 children that were in between two years and under five years of age. The children $(\mathrm{n}=240)$, $(n=127)$ and $(n=73)$ out of total 440 were taken from schools, anganwadis and slums, respectively, as in Table 1 . The proportion of children was $54.5 \%, 28.9 \%$, and $16.6 \%$ in schools, anganwadis and slums, respectively, as in Table 2.
Table 2 : Strata-wise Distribution of Participants

\begin{tabular}{|l|l|l|}
\hline $\begin{array}{l}\text { Demographic } \\
\text { Characteristics }\end{array}$ & $\begin{array}{l}\text { Percentage } \\
\text { (n\%) }\end{array}$ & $\begin{array}{l}\text { Frequency } \\
(\mathbf{n} / \mathbf{N})\end{array}$ \\
\hline Schools & $54.5 \%$ & $240 / 440$ \\
\hline Anganwadis & $28.9 \%$ & $127 / 440$ \\
\hline Slums & $16.6 \%$ & $73 / 440$ \\
\hline
\end{tabular}

\section{Age predilection and stunting Descriptive analysis}

The study revealed $40 \%$ prevalence of stunting in children in age group between $2 \mathrm{y}$ to $3 \mathrm{y}$ that comprised of $(n=68 / 169)$ children as in Table 3 . Another prevalence $21 \%$ of stunting was found in children in age group between more than 3 to below 5 years that was comprised of $(\mathrm{n}=58 / 271)$ children as in Table 3 .

The study revealed overall stunting prevalence of $28.6 \%$ that was comprised of children $(n=126 / 440)$ between 2 years and under 5 years of age. Furthermore, the prevalence of stunting was higher as (40)\% in age group of children between 2-3 years and the prevalence of stunting was lower as $(21 \%)$ in age group of children between $(>3-<5)$ years.

\section{Correlation analysis}

The children in age group (2-3 years) showed odds for stunting in children as (Odds $=0.67)$, while the odds in age group between $(>3-<5$ years) was (odds $=0.27$ ) for stunting in children as in table 4. The odds ratio between the two age groups (age group 2-3 years/ age group $(>3-<5$ years $)$ was $(\mathrm{OR}=2.47)$ at $95 \%$ C.I. with range in between 1.58 to 3.86 as in Table 4 .

The stunting in children in 2-3 years age group showed 2.47 times higher chances than the stunting probability in children above 3 to below 5 years age.

\section{Inferential analysis}

Inferential analysis was done by Chi-square test of independence. In the present study, test statistics as $\left(\chi^{2}=18.07\right)$ at degree of freedom $=1$ was higher than the critical value $\left(\chi^{2}=3.84\right)$ at $\mathrm{df}=1)$ as in Table 4. At implied $(\mathrm{p}<0.05)$ value, the alternate hypothesis was accepted at $5 \%$ significance level. 
Table 3 : Age predilection and Stunting in Preschool children

\begin{tabular}{|l|l|l|}
\hline Characteristics & $\begin{array}{l}\text { Children (2-3 } \\
\text { year) } \\
\text { (n=169) }\end{array}$ & $\begin{array}{l}\text { Children } \\
(>3-<5 \\
\text { year) } \\
(\mathbf{n}=271)\end{array}$ \\
\hline $\begin{array}{l}\text { Stunted } \\
\text { children }\end{array}$ & $\begin{array}{l}68 / 169 \\
(40 \%)\end{array}$ & $\begin{array}{l}58 / 271 \\
(21 \%)\end{array}$ \\
\hline $\begin{array}{l}\text { Normal } \\
\text { children }\end{array}$ & $\begin{array}{l}101 / 169 \\
(60 \%)\end{array}$ & $\begin{array}{l}213 / 271 \\
(79 \%)\end{array}$ \\
\hline
\end{tabular}

4. Age predilection and Pallor in Preschool children

\section{Descriptive analysis}

In the present study, descriptive analysis provided $26 \%$ prevalence of pallor in preschool children. Further analysis yielded $16.5 \%$ prevalence of pallor in the children $(28 / 169)$ and $32 \%$ prevalence of pallor in children $(87 / 271)$ in the age categories $(2 y-3 y)$ and $(>3 y-<5 y)$, respectively, as in table 4 .

\section{Correlation analysis}

The correlation analysis between age groups and pallor was performed by calculation of Odd ratio with $95 \%$ C.I. The Odd ratio between age groups and pallor in preschool children was $(\mathrm{OR}=0.1986 / 0.4728)=(0.42)$ at $95 \% \mathrm{C}$. I. of $(0.260$ to 0.628$)$. The probability of pallor in children in $2 y$ to $3 y$ age group was $58 \%$ less in comparison to probability of pallor in children in age $>3 \mathrm{y}$ to $<5 \mathrm{y}$.

Inferential analysis :

The Odd ratio was confirmed by Chi square test for independence that yielded a value $\left(\chi^{2}=\right.$ 13.1 atdf $=1)$ at significance level $(\mathrm{p}=0.0003)$. It was compared with the table value $\left(\chi^{2}=3.84\right.$, at $\mathrm{df}=1)$ at significance level of $5 \%$ as in Table 4. Therefore, the alternate hypothesis was accepted at 55 significance level.

Table 4 : Age predilection and Pallor in Preschool children

\begin{tabular}{|l|l|l|}
\hline Characteristics & $\begin{array}{l}\text { Percentage } \\
\text { of Pallor in } \\
\text { children }\end{array}$ & $\begin{array}{l}\text { Percentage } \\
\text { of Normal } \\
\text { children }\end{array}$ \\
\hline 2years to 3years & $\begin{array}{l}28 / 169 \\
(16.5 \%)\end{array}$ & $\begin{array}{l}141 / 169 \\
(83.4 \%)\end{array}$ \\
\hline $\begin{array}{l}\text { > 3years to } \\
\text { <5years }\end{array}$ & $\begin{array}{l}87 / 271 \\
(32 \%)\end{array}$ & $\begin{array}{l}184 / 271 \\
(68 \%)\end{array}$ \\
\hline
\end{tabular}

\section{Age predilection and Dental caries in Preschool children \\ Descriptive analysis}

It provided as $11.2 \%$ prevalence of dental caries in preschool children in present study. Further, analysis yielded a segmental prevalence of $9.5 \%$ in age group between $2 y$ to $3 y$ and prevalence of $12.9 \%$ of dental caries in children in age group between $>3 y$ to $<5$ years in fazilka city.

\section{Correlation analysis}

The Odds ratio between the two age groups was calculated as $(\mathrm{OR}=0.705)$ at $95 \% \mathrm{CI}$ in between $(0.377$ to 1.318$)$ at $5 \%$ significance level.

\section{Inferential analysis}

The inferential analysis was conducted by Chi square test of Independence. Its value was $\left(\chi^{2}=1.207\right.$ at $\left.\mathrm{df}=1\right)$ with value $(\mathrm{p}=0.27)$ and it was compared with the test statistics. The alternate hypothesis was rejected at 5\% level of significance.

Table 5 : Age predilection and Dental caries in Preschool children

\begin{tabular}{|c|c|c|}
\hline Characteristcis & $2 y$ to $3 y$ & $>3 y$ to $<5 y$ \\
\hline $\begin{array}{ll}\begin{array}{l}\text { Dental } \\
\text { frequency }\end{array} & \text { caries } \\
\end{array}$ & $16 / 169$ & $35 / 271$ \\
\hline $\begin{array}{ll}\text { Dental } & \text { caries } \\
\text { percentage } & \end{array}$ & $9.5 \%$ & $12.9 \%$ \\
\hline
\end{tabular}

\section{DISCUSSION :}

In the present study, prevalence of $28.6 \%$ of stunting in preschool children is mentioned in the city Fazilka in Punjab, India. In the previous study, prevalence of $26.7 \%$ of stunting was described by (De Onis et al. 2011 [6]). In another previous work in Sri Lanka, the prevalence of $15 \%$ stunting was described by (Thamilini et al. 2015 [7]).

The prevalence of stunting in younger age group is more marked than the stunting in older age group. It is caused by multiple factors as weaning, food availability, environmental factors, and clean drinking water.

In present study, higher prevalence of dental caries is described in older age group of children. Dental caries is a disease of poor oral hygiene. The age related higher prevalence of dental caries in older age is non-significant in the present study. In previous study, (Priyadarshini et al. 2011 [8]) described higher 
prevalence of dental caries in older age group of children.

Pallor is the clinical sign of anemia in children. In the present study, the prevalence of pallor was lesser significantly in comparison to prevalence of pallor in older age group of children. In the previous study, authors (Getaneh et al. 2000 [9]), contradicted the findings in the present study, wherein, the prevalence of pallor was higher in the younger age of children. The explanation of higher prevalence of pallor in the older age in children in the present study is the tendency of eating junk foods among the old aged children. They eat processed foods that are devoid of nutrition and minerals especially iron and rich in trans-fats. The children in the older age group are more habitual of eating these food items. These foods lead to obesity and iron deficit anemia in children.

Pallor is the manifestation of iron deficiency anemia in children. It is detrimental to the health of children. it impedes the physical growth and cognitive development in the children in preschool age whose effect persists in the later periods of life. There should be composite input by the clinicians and health workers in the screening of anemia among children and the remedial steps should be taken to improve the diet of children to eradicate anemia in the children.

\section{CONCLUSION :}

Malnutrition in the children is associated with the age of children. The manifestations as stunting, pallor, diarrhoea, and dental caries are age related clinical manifestations among the children. These disorders negatively affect the health of children. The effective screening and corrective measures are necessary to improve the nutritional status of preschool children.

\section{REFERENCES :}

[1] World Bank (2012). Poverty Overview. Available at: http://www.worldbank.org/en/topic/pover ty.

[2] Kosek M, Bern C, Guerrant RL (2003). The global burden of Diarrhoeal disease, as estimated from studies published between 1992 and 2000. Bull World Health Organ 81:197-204.
[3] Black R.E., Victora CG, Walker S.P., Bhutta Z.Q., Christian P, Onis M (2013). Maternal and child under nutrition and overweight in low-income and middleincome countries. Lancet 382(9890):42751.

[4] Weber M W, Kellingray S D, Palmer A, Jaffar S, Mullholland EK, Greenwood BM (1997). Pallor as a clinical sign of severe anaemia in children: an investigation in the Gambia. Bull World Health Organ. 75 (4):113-8.

[5] Mohammadi, T. M., \& Kay, E. J. (2012). Effect of dental caries on children growth. Dr Ming Yu Li. Contemporary Approach to Dental Caries. In Techopen Publications, 379-94.

[6] De Onis M, Blossner M, Borghi E (2011). Prevalence and trends of stunting among pre-school children 1990-2020. Public Health Nutr. Available from: http://www.who.int/nutgrowthdb/publicat ions/Stunting1990 2011.pdf.

[7] Thamilini J, Silva KD, Jayasinghe JM (2015). Prevalence of stunting among preschool children in food insecure rural households in Sri Lanka. Trop Agric Res 26(2):390-4.

[8] Priyadarshini H. R., Hiremath S. S., Puranik M., Rudresh S. M., Nagaratnamma T (2011). Prevalence of early childhood caries among preschool children of low socioeconomic status in Bangalore city, India. J IntSoc Prevent Communit Dent 1: 27-30.

[9] Getaneh T, Girma T, Belachew T, Teklemariam S (2000). The utility of pallor detecting anemia in under five years old children. Ethiop Med. J 38 (3):77-84. 